Batı Karadeniz Tıp Dergisi

Medical Journal of Western Black Sea
Med J West Black Sea 2021;5(1): 19-26

DOI: $10.29058 /$ mjwbs.776644

\title{
Lezzet Algısının Olușmasında Çevresel ve Genetik Faktörlerin Etkileri
}

\section{Effects of Environmental and Genetic Factors on the Taste Perception}

\author{
Mücahit MUSLU1 (D), Gülden Fatma GÖKÇAY² \\ ${ }^{1}$ Kastamonu Üniversitesi, Sağlık Bilimleri Fakültesi, Beslenme ve Diyetetik Bölümü, Kastamonu, Türkiye \\ 2 İstanbul Üniversitesi, İstanbul Tıp Fakültesi, Çocuk Sağlığı ve Hastalıkları Anabilim Dalı, İstanbul, Türkiye
}

ORCID ID: Mücahit Muslu 0000-0002-8761-5061, Gülden Fatma Gökçay 0000-0003-3726-5726

Bu makaleye yapılacak atıf: Muslu M ve Gökçay GF. Lezzet Algısının Olușmasında Çevresel ve Genetik Faktörlerin Etkileri. Med J West Black Sea. 2021;5(1):19-26.

Sorumlu Yazar

Mücahit Muslu

E-posta

dytmuslu@gmail.com
Geliș Tarihi

04.08.2020

Revizyon Tarihi

10.12.2020

Kabul Tarihi

11.12.2020
ÖZ

Lezzet algısı kimyasal, hormonal ve sinirsel uyarılarla oluşan, birçok organ ve hormonun etkili olduğu karmaşık bir sistemdir. Lezzet algısı genel olarak hissedilen tat, koku, doku ve görsel uyarıların bir bütünü olarak değerlendirilmektedir. Yaş, cinsiyet, hastalıklar, psikolojik durum, gebelik, obezite varlığı, sigara kullanımı, sosyokültürel etmenler, beslenme ve besin ögeleri gibi birçok çevresel ve genetik faktöre göre değișiklik göstermektedir. Bu algı besin tercihleri ve besin tüketimini etkileyen önemli bir faktördür. Acı, tatı, ekşi, tuzlu ve umami tatları dışında yağ, nişasta ve metalik tatlar lezzet algısını etkilemektedir. Lezzet algısı, tat algılamada görevli reseptörleri üreten genlerde bulunan genetik polimorfizmlerle kısmen açıklanabilmekte ve bireyler arasında büyük farklılıklar göstermektedir. Bu tatların algılanmasında TAS1R, TAS2R, CA6, TRPV, SCNN, PKD1 gibi gen aileleri ve reseptörler etkili olmaktadır. Bu nedenle lezzet algısının genetik ve çevresel faktörlerinin daha iyi anlaşılması için kaliteli çalışmaların artması gerekirken, bu konu besin tercihlerinin anlaşılması ve çağımızın sorunu beslenme kökenli hastalıklarla mücadele konusunda büyük önem taşımaktadır.

Anahtar Sözcükler: Tat, Lezzet, Tat algısı, Lezzet algısı, Beslenme

\section{ABSTRACT}

Taste perception is a complex system consisting of chemical, hormonal and neural stimuli involving many organs and hormones. Taste perception is generally evaluated not only as the taste felt, but also as a combination of smell, texture and visual stimuli. It varies according to many environmental and genetic factors such as age, gender, diseases, psychological status, pregnancy, presence of obesity, smoking, sociocultural factors, nutrition and nutrients. This perception is an important factor affecting food preferences and food consumption. Apart from bitter, sweet, sour, salty and umami flavors, oil, starch and metallic flavors affect the perception of taste. Taste perception can be partially explained by genetic polymorphisms found in genes that produce receptors involved in taste perception and show great differences between individuals. Gene families and receptors such as TAS1R, TAS2R, CA6, TRPV, SCNN, PKD1 are effective in the detection of these flavors. For this reason, increasing the qualified studies in order to understand the genetic and environmental factors of taste perception that is of great importance in understanding nutritional preferences and fight against nutritional diseases of our age.

Keywords: Taste, Flavor, Taste perception, Flavor perception, Nutrition 


\section{GiRiş}

Küreselleşmeyle birlikte beslenme davranışları üzerinde büyük değişiklikler meydana gelmiş ve sağlıksız beslenme davranışları dünya genelinde mortalite ve morbidite oranlarını artırmıştır. Yüksek tuz, yağ ve şeker içeriğine sahip endüstriyel besinlerin tüketiminin olumsuz beslenme davranışları ile beraber artması önemli bir halk sağlığı sorunu hâline gelmiştir (1). Besin alımı, bireysel besin tercihleri ile yakından ilişkili olup lezzet algısından etkilenmektedir. Bu nedenle besin tercihlerinin nedenlerini anlamak, beslenme davranışını değiştirmeyi hedefleyen halk sağlığı programlarının tasarlanması ve uygulanması için gerekmektedir (2). Lezzet algısı kimyasal, hormonal ve sinirsel uyarılarla oluşur. Yaş, cinsiyet, hastalıklar, psikolojik durum, gebelik, obezite, sigara kullanımı, sosyokültürel etmenler, beslenme ve besin ögeleri gibi birçok çevresel ve genetik faktöre göre değişiklikler göstermektedir (3).

Lezzet denilince tatı, acı, ekşi, tuzlu, umami gibi temel tatlar ve son zamanlarda çalışılan yağ tatları akla gelmektedir. Bununla birlikte tat ve lezzet kavramları konusunda net bir tanım yapılamamaktadır. Lezzet algısı genel olarak sadece hissedilen tat değil koku, doku ve görsel uyarıları da kapsayan bir bütün olarak değerlendirilmektedir. Bu nedenle birçok duyu organı lezzet algısında etkilidir $(4,5)$. Özellikle koku duyusu lezzet konusunda tat duyusundan sonra en fazla etkili olan duyudur. Örneğin soğuk algınlığı döneminde tatların algılanmasında azalma burundaki kimyasal sürecin engellenmesine bağlı olarak koku duyusunun tam çalışmaması ile açıklanmaktadır $(6,7)$. Lezzet algısı birkaç işlevsel nedenden dolayı büyük önem taşımaktadır. Lezzet hissi vücudun besin gereksinimlerine göre zamanla değişebilmekte böylece eksikliği olan besin ögesinin tüketilmesi desteklemektedir. Aynı zamanda acı tatlar zehirli olabilecek besinler için uyarı niteliği taşımakta olup evrimsel süreçte zararlı besinlerden koruyucu etki sağlamıştır (7). Bu derlemede lezzet algısını etkileyen çevresel ve genetik faktörler ve beslenme üzerine etkilerinin güncel çalışmalar ile değerlendirmesi amaçlanmaktadır.

\section{LEZZET ALGILAMA FIZYOLOJisi}

Dilimizde tadın algılanmasında önemli rolü olan, sayıları yaşa göre değişmekle birlikte 4000 ile 9000 arasında değişen tat tomurcuğu (papilla) bulunmaktadır. Bu tomurcukların sayısı çocukluk döneminde çok yüksek olup yaş ilerledikçe azalmaktadır (8). Tat tomurcukları ağız boşluğuna yayılmış olarak bulunur ve her birinde farklı tatları algılamak için özelleşmiş 50 ile 100 nöroepitelyal hücre vardır. Tat tomurcukları içerdikleri reseptörlere göre dilin farklı bölgelerinde yoğunlaşmıştır (9). Nöroepitel hücreler dört gruba ayrılmaktadır. Tip 1 tat hücreleri en fazla oranda olup tuzlu tatların algılanmasından sorumludur. Tip 2 tat hücreleri yüzeylerinde spesifik reseptör proteinleri bulundurarak tatlı, acı ve umami tatlarının algılanmasından sorumludur. Tip 3 tat hücreleri ekşi tadı algılarken, tip 4 tat hücrelerinin işlevi tam olarak bilinmemektedir (10). Lezzet algısında önemli bir diğer organ koku algılamasını sağlayan burundur. Nazal boşluğun en üst bölgesinde koku reseptörlerinin bulunduğu olfaktör bölge bulunur ve fizyolojik olarak burundan alınan havanın \%15'i bu bölgeden geçerek koku reseptörlerini uyarır. Bu uyarının olabilmesi için olfaktör bölgedeki mukusta kimyasal çözünme gerçekleşmelidir. Kimyasal çözünme sonrası algılanan maddeler elektriksel uyarılmayı sağlayarak sinirsel iletimi başlatır (11). Uçucu veya çözünen bileşenler arasındaki fiziksel ve kimyasal etkileşimler hem dil hem de burundaki reseptörler ile tat-koku maddelerinin yoğunluğunun algılanması ve birlikte değerlendirilmesi ile lezzet algısının oluşmasını etkilemektedir (12).

Lezzeti algılama fizyolojisi ağıza alınan besinlerin tükürük salgısında bulunan enzimler ile sindirilmesi veya çözünmesi ile başlar. Bu nedenle lezzet algısının oluşabilmesi için ilk başta kimyasal çözünme gerekmektedir. Sindirilen veya çözünen kimyasallar tat tomurcuklarındaki tat reseptörlerine ulaşır. Acı ve tatı tatlar G-proteine bağlı reseptörlerle algılanır. Ekşi ve tuzlu tatlar sinir sinyalinin doğrudan yayılmasına neden olan iyon kanallarını aktive eder. Umami tat ise hem G-protein bağlı reseptörler hem de iyon kanallarını uyararak algılanır. Tat tomurcuklarında işlenen bilgiler üç kranial sinirden (fasiyal, glossofaringeal ve vagus) afferent liflere iletilir. Tat uyaranlarının kimyasal kimliğine ilişkin sinyaller, talamusa çıkmadan ve kortekse ulaşmadan önce beyin sapı çekirdeği 'tractus solitarius' tarafından işlenir. Oradan, talamusun ventral posteromedial çekirdeğine devam eder ve daha sonra üçüncü dereceden nöronlar tarafından daha yüksek seviyeli kortikal tat merkezlerine aktarılır. Bazı bilgiler, lateral ve dorsomedial çekirdeklerin yeme davranışlarını düzenlemede önemli rol oynayan hipotalamusa iletilir. Bu çekirdekler esas olarak tokluk ve açlık arasındaki dengeye aracılık eden leptin ve ghrelin hormonlarından etkilenir. Lezzetin algılanma süreci kimyasal çözülme ve elektriksel iletim ile devam eden farklı organlar ve hormonlardan etkilenen kompleks bir sistemdir $(7,9,13)$.

\section{LEZZET ALGISINI ETKILEYEN FAKTÖRLER}

\section{Beslenme ve Besin Çeşitliliği}

Tat tomurcuklarının aktivasyonu, hamileliğin otuzuncu haftasında başlamaktadır. Bu süreçte maternal diyet amniyotik sıvı içeriğini etkileyerek fetal tat reseptörlerini ilk defa uyarmaktadır. Bu erken aktivasyon, bebeğin tat tercihini etkileyerek gelecekte besin seçiminde etkin olan tat duyusal hafızasının geliştirilmesinde ilk adımı oluşturmaktadır. Aynı süreç doğum sonrasında anne sütü alımı ile devam etmektedir (14). Anne sütündeki önemli bileşikler tatlı tadı için laktoz, umami tadı için glutamat, tuzlu tadı için sodyum, acı tadı için üre ve yağlı tadı için uzun zincirli yağ asitleri gibi spesifik tatlar sağlamaktadır $(15,16)$. Anne sütü almadan formül süt ile 
beslenen çocuklar, anne sütünün zengin lezzet profilinden faydalanamamaktadır. Annenin diyetindeki çeşitli maddelerin tatlarını deneyimlemedikleri için lezzet deneyimleri daha zayıf olmaktadır (17). İngiltere, Yunanistan, Fransa ve Portekiz'de yapılan dört kohortu kapsayan bir çalışmada anne sütü alım süresinin artmasının okul öncesi dönemde sebze ve meyve tüketimini arttırdığı bulunmuştur. Anne sütü alım süresinin okul öncesi dönemde besin tercihlerini etkileyebileceği vurgulanmıştır (18).

Tamamlayıcı beslenme dönemi lezzet algısını etkileyen bir diğer önemli dönemdir. Bu dönemde bebeğin tüketimine uygun ve çeşitli besinler içeren bir beslenme önerilmektedir. Bu dönemde çeşitli besinlerin sunulması farklı besin ögelerinin eksikliğini önlemesi dışında bebekte taT algısının da gelişimini destekler. Anne sütü dışında ilk defa farklı besinlerle tanışan bebek ne kadar çok çeşit besinle beslenirse o kadar yüksek lezzet hafızası oluşacak ve ilerleyen dönemlerde farklı besinleri tüketimi kolaylaşacaktır (19). Genel olarak bakıldığında prenatal ve postnatal dönemde annenin besin çeşitliliği fazla olan bir beslenme planı uygulaması, bebeğin iki yaşına kadar anne sütü alması ve tamamlayıcı beslenme döneminde besin çeşitliliğinin sağlanması bebeğin lezzet hafızasını güçlendirerek farklı besinleri kabulünü artırmaktadır. Bu dönemde kazanıımış davranışların tat algısı üzerinden besin seçeneklerine etkileri yaşamın ilerleyen evrelerine olumlu davranışlar olarak taşınmaktadır (20).

Tat reseptörleri sadece ağız boşluğunda değil gastrointestinal sistemde ve diğer dokularda da bulunmaktadır. Bu nedenle lezzet algısı ve besin seçimi arasındaki ilişki karşıııIıdır (21). Tat algısındaki farklılıklar sadece besin seçimi ile sınırlı değil, aynı zamanda besin ögelerinin gastrointestinal sistemde fizyolojik yanıtı ve metabolizmasındaki farklılıklarına da dayanmaktadır. Reseptörlere bağlı olarak besin seçimi yapııdığı gibi besin tüketimine bağlı olarak reseptör yanıtı da değişebilmektedir (22).

\section{Yaş ve Cinsiyet}

Lezzet algısı çocukluk döneminde en yüksek düzeyde olup yaşın ilerlemesiyle dilde bulunan tat tomurcuklarının hasar görmesi sonucunda azalmaktadır (8). Aynı zamanda yaşlanmayla birlikte artan hastalıkların etkisi, çiğneme fonksiyonundaki azalmalar, sinirsel iletim sorunları, kullanılan ilaçlar gibi nedenlerle beş tat duyusunda da gençlere göre kademeli olarak azalma görülmektedir. Bu azalmaların seviyesi kişilere göre değişmektedir $(23,24)$. Yaşlanmaya bağlı olarak gerçekleşen tat bozuklukları \%21,7 ilaç kullanımı, $\% 14,5$ çinko eksikliği, \%7,4 oral hastalıklar ve \%6,4 sistemik hastalıklar nedeniyle oluşmaktadır (25). Aynı zamanda 60 yaş üzerinde besinlerin dokusunu hissetmede kayıplar yaşandığı ve \%50'sinden fazlasında koku algılama kaybı olduğu bilinmektedir (23). Finlandiya'da tat algısı üzerine yapılan bir çalışmada 50 yaş üzeri kişilerin genel popülasyona göre tat algısının daha düşük olduğu ve özellikle umami tadı duyarııı̆ının ileri yaşla ters ilişkili olduğu belirtilmiştir (26). Farklı bir çalışmada da artan yaşın tuzlu tada yanıt vermede ve koku algısında azalma ile ilişkili olduğu bulunmuştur (27)

Lezzet algısının cinsiyete göre değerlendirmesinde net bir değerlendirme yapılamamaktadır. Ancak genelde genetik olarak kadınların daha iyi tat ve koku algıladığı düşünülmektedir (3). Cinsiyetin lezzet algısı üzerine etkisini inceleyen bir çalışmada kadınların koku ve tat algı düzeyinin, erkeklerin ise besin tüketim düzeylerinin daha yüksek olduğu bulunmuştur (28). Beş tat duyusunun da değerlendirildiği bir çalışmada kadınların lezzet algısının erkeklere göre önemli ölçüde fazla olduğu bildirilmiştir (25). Finlandiya'da yapılan çalışmada da erkeklerin lezzet algısının daha düşük olduğu görülmüştür (26). Farklı bir çalışmada ise lezzet ve koku algısı cinsiyet ile ilişkili bulunmamıştır (27). Aynı zamanda kadınlarda besinlerden iğrenme duyarlıığının erkeklere göre daha fazla olduğu bildirilmiştir (29). Sükroz algısı üzerine 7-14 yaş çocuklarla yapılan bir çalışmada kızların erkeklerden daha duyarlı olduğu ve büyük çocukların küçüklere göre daha fazla duyarlı olduğu bildirilmiş̧ir. Aynı zamanda acı tat reseptörlerindeki varyantların bu algıyı etkileyebildiği belirtilmiştir (30).

\section{Hastalıklar ve Tedavileri}

Hastalıklar ve hastalıklara bağlı ilaç kullanımı nedeniyle tat ve koku kayıpları oluşmakta ve lezzet algısı olumsuz yönde etkilenmektedir (25). Özellikle oral alımın engellendiği ve tüple beslenme uygulanan hastalıklar tat ve koku duyusunun uzun süre baskılanmasına ve lezzet algısında azalmaya neden olmaktadır. Disfajili amiyotrofik lateral skleroz hastalarında yapılan çalışmada hastalığa bağlı olarak lezzet algısındaki değişikliklerin hastaların yaşam kalitesini olumsuz yönde etkilediği ve özellikle enteral tüple beslenen hastalarda bunun daha fazla olduğu bulunmuştur (31). İnflamatuvar sürecin artması tat bozuklukları için kilit rol oynamaktadır. Kanser hastalarında kemoterapiden bağımsız olarak tatlı, tuzlu ve umami tadı algılama eşiklerinin arttığı belirtilmiştir. Kansere bağlı inflamasyonun, tat algısı üzerinde akut inflamatuar süreçten daha büyük bir etkisi olduğu bildirilmiştir (32). Tatlar kan basıncındaki değişikliklerle de ilişkilendirilmiştir. Hipertansiyonun lezzet algısı kaybı ile ilişkisi, anti-hipertansif ilaçların kullanımıyla maskelenebilmektedir. Çünkü bu ilaçlar hipojezi ve tat kaybına neden olmaktadır (33). Pediatri hastaları üzerinde lezzet algısının incelendiği bir derlemede anoreksiya nervoza hastalarında, kemoterapi ve kemik iliği nakli yapılan kanser hastalarında, kronik böbrek hastalarında ve diş çürüğü olan hastalarda dört temel tatta genel bir azalma görüldüğü bildirilmiştir (34).

Obezite gelişimi tat tomurcuklarında önemli bir azalma ile ilişkilidir. Bozulmuş tat tomurcuğu duyarlılığı, çocuklarda ve ergenlerde obezitenin patofizyolojisinde nedensel bir rol oynamaktadır (35). Obez bireylerde lezzet algısının farklı tatlara göre değişiklik gösterdiği bilinmektedir. Obezitenin 
neden olduğu tat değişiklikleri veya tat değişikliklerine bağlı obezite durumu olabilmektedir. Obezitenin özellikle umami ve tatlı tatlarla ilişkili olduğu belirtilmektedir $(26,27,34)$. Ayrıca oral mikrobiyotanın lezzet algısı üzerinde etkili olabileceği ve buna bağlı olarak besin tüketimi ve obezite ile ilişkili olabileceği bildirilmiştir (36).

\section{Gebelik ve Laktasyon}

Gebelik ve laktasyon sürecinde çeşitli hormonların etkisiyle tat algısında azalma veya bozulma görülebilmektedir. Bu nedenle hamilelerin belli tatlara ve bu tatların bulunduğu besinlere karşı ilgileri değişebilmektedir (37). Gebelik dönemi ve lezzet algısı ile ilgili 14 çalışmanın incelendiği bir derlemede hamile kadınların ilk trimesterde acı tat eşiklerinin daha yüksek olduğu, hamilelik süresince tuzlu tatlara ilgi artarken tatlı tatlara karşı azaldığı, acı ve ekşi tatlarda ise bir değişikliğin olmadığı bildirilmiştir (38).

\section{Diğer Faktörler}

Vücutta inflamasyonun artmasının lezzet algısı üzerinde olumsuz etkileri bulunmaktadır (32). Tütün ürünleri lezzet algısı için risk oluşturan ürünlerdir. Sigara içen bireylerin içmeyenlere göre lezzet algıları azalmakta ve lezzetleri algılama süreleri uzamaktadır (39). Alkol tadı̈zellikle acı tat reseptörleri ile ilişkilidir. Bu nedenle genetik olarak acı tat eşiği yüksek olan kişilerde alkol tüketimi daha fazla olabilmekte ve alkolizm riskleri artmaktadır. Bu nedenle tüketime bağlı olarak lezzet algısı değişebileceği gibi genetiğe bağlı tat reseptörlerinin varlığı bağımlılık durumunu etkileyebilmektedir (40).

Etnik kökenler arasındaki genetik veya kültürel farklılıklar besin tüketimini ve tercihlerini etkilemektedir. Etnik köken ve tat algısındaki farklılıkların incelendiği bir çalışmada Hispanik ve Afrikalı Amerikalılar lezzet algı düzeylerini Hispanik olmayan beyaz Amerikalılardan daha fazla olduğunu be- lirtmiştir. Bu oranın erkeklerde daha fazla olduğu bildirilmiştir. Çalışma sonucunda aynı besinlere farklı etnik kökenlere sahip kişilerin farklı derecede tepki verebileceği belirtilmiştir (41).

\section{GENETIK FAKTÖRLER VE LEZZET ALGISI}

Lezzet algısı, tat algılamada görevli reseptörleri üreten genlerde bulunan polimorfizmlerle kısmen açıklanabilmekte ve bireyler arasında büyük farklılıklar göstermektedir. Bazı tatlarla ilgili reseptör aileleri ve bu reseptörleri uyaran besin maddeleri geniş farklııklar göstermektedir. Aynı zamanda reseptörlerden bazılarının farklı tatlar için ortak uyarıcıları olabilmektedir. Genel olarak bilinen tatlar ve hislerin reseptör ve etkileyen bileşikleri Tablo 1'de verilmiştir $(4,42)$.

Tüm tat duyuları arasında acı tat reseptörlerini kodlayan genler en geniş sınıfı oluşturmaktadır. Acı tat reseptör ailesi (TAS2R'ler) en az 25 bilinen gen içerir ve bu genlerde birbirleriyle yakından ilişkilidir. Ayrıca bu genlerde meydana gelen tek nükleotid polimorfizmleri (SNPs) de farklılığa neden olmaktadır (43). Diğer tatlara göre daha yüksek oranda acı tat reseptörünün bulunması aynı zamanda otçul hayvanlarda bu oranın yüksek olması evrimsel süreçte çok çeşitli bitkisel türün besin maddesi olarak tüketildiğinin göstergesi olarak yorumlanmaktadır (44). Acı tatların algılanmasının bitkilerde bulunan zehirli maddelerin fark edilmesi için evrimsel süreçte gelişim gösterdiğine inanılmaktadır (7). Acı reseptörü ile ilgili ilk çalışma Blakeslee (1932) tarafından yapılmıştır. Feniltiyokarbamidden (PTC) ve 6-n-propiltiorasil'in (PROP veya PTU) farklı kişilerde algılanma düzeyinin değiştiği gözlemlenmiştir. Beyaz bireylerin yaklaşık\% 25'inin PTC/PROP'u çok acı algıladığını, \%25'inin çok az ya da hiç acı hissetmediğini, kalan \%50'lik kısmın ise aralarda bir yerde bulunan daha ılımlı bir yanıta sahip olduğu belirtilmiştir. Daha sonra bu yanıtın tat alıcı gen TAS2R38'deki bir gen varyantının sorumlu olduğu anlaşılmıştır $(45,46)$. Bugüne

Tablo 1: Tatlar ve hislerin algılanmasında ilgili gen-reseptör-kanal ve bileşikler $(4,42)$

\begin{tabular}{lll}
\hline Duygular & Gen - Reseptör - Kanal & Örnek Bileşikler \\
\hline Tatlar & & \\
\hline Acı & TAS2R ${ }^{*}$, CA6 & PROP, Kinin, Kafein, Piperin, Kapsaisin, Alkol \\
\hline Tatlı & TAS1R2, TAS1R3, TAS2R38 & Sükroz, Sükraloz \\
\hline Umami & TAS1R1, TAS1R3, GRM1, GNAT3 & $\begin{array}{l}\text { Monosodyum glutamat(MSG), İnosin monofosfat(IM), } \\
\text { Guanozin monofosfat(GM) }\end{array}$ \\
\hline Tuzlu & ENaC, TRPV1, SCNN1*, CA6, TAS2R38 & NaCL, KCL \\
\hline Ekşi & PKD2L1, PKD1L3, Kir2.1 & Sitrik asit, Laktik asit, Asetik asit, Malik asit, Tartarik asit \\
\hline Yağlı (Oleogustus) & CD36, GPR120, IZUMO1 & Linoleik asit, Oleik asit \\
\hline Kemestez/Hisler & & \\
\hline Yanma/lsınma & TRPV1 & Kapsaisin, Ethanol \\
\hline Soğuma & TRPM8 & Mentol, Nane \\
\hline
\end{tabular}

*Birçok alt türü bulunmaktadır. 
kadar tat ile ilgili genotip-fenotip çalışmalarının çoğu en yaygın TAS2R tat reseptör varyantlarını barındıran TAS2R38'e odaklanmıştır. Bununla birlikte, geri kalan yaklaşık 24 acı tat reseptörünün en az 10'u yiyecek ve içeceklerde bulunan çok çeşitli kimyasallar için ekspresyon seviyesi ve/veya tat fonksiyonu üzerinde etkisi olabilecek SNPs içermektedir. Acı reseptörleri ile yapılmış olan çalışmalardaki genler, genlerdeki SNP sayıları, reseptördeki ligand numaraları, besinlerle ilişkili bulunan ligandlar, tat reseptörleri ile ilişkili besinler ve tat algısını etkileyen beslenme davranışları Tablo 2'de verilmiştir (46).

Tatlı tatlar TAS1R reseptör ailesine bağlı TAS1R1, TAS1R2, ve TAS1R3 reseptör genleri tarafından algılanmaktadır. Acı reseptörleri tek başına hareket ederken tatlı (TAS1R1, TAS1R3) ve umami (TAS1R2, TAS1R3) reseptörleri çiftler halinde hareket eden alt birimleri kodlamaktadır. Doğal şekerler, besin değeri olmayan tatlandırıcılar, amino asitler ve proteinler tatlı tat tepkisini uyarmaktadır. Bunlar tatı tat reseptörü içindeki farklı yerlere bağlanarak tatlı tat algısında farklılıklara neden olabilmektedir (47). Tat algısı konusunda sadece genlere bakmak yanlış yorumlamalara neden olabilmektedir. Acı tattan sorumlu olan TAS2R38 aynı zamanda tatlı ve umami içinde etkileşim doğurabilmektedir. Bu nedenle farklı tatlar arasında algılamayı etkileyecek etkileşimler mevcuttur (48).

Dilde en fazla miktarda bulunan Tip 1 tat hücreleri tuzlu tadın algılanmasından sorumludur. (10). Tuzlu tat genellikle tuz içeren besinlerin alınması ile sinir sinyalinin doğrudan yayılmasına neden olan iyon kanallarını aktive olmasıyla algılanır $(7,13)$. Tuzlu tada yanıt verme yeteneğinin moleküler mekanizması net değildir. Tat tomurcuklarında bulunan amiloride duyarlı vanilloid reseptörler (TRPV1) ile tat hücresi zarlarında bulunan epitelyal sodyum kanallarının (ENaC) tutulumu tuzlu tat algısıyla ilişkilendirilmiştir $(13,49)$. Tuz reseptörlerinde bulunan polimorfizmler de lezzet algısını değiştirebilmektedir. Yapılan bir çalışmada TRPV1 rs8065080 (CC genotipi), SCNN1B rs239345 (AA genotipi) ve rs3737665 (TT genotipi) homozigotlarının tuz çözeltilerini heterozigotlardan veya diğer homozigotlardan önemli ölçüde daha zayıf algıladığı bildirilmiştir (50).

Tablo 2: Acı tat algısı (TAS2R) ile yapılmış çalışmaların özeti (46)

\begin{tabular}{|c|c|c|c|c|c|}
\hline TAS2R & $\begin{array}{l}\text { Ligand } \\
\text { Sayısı }\end{array}$ & Besin ile ilgili ligandlar & $\begin{array}{l}\text { SNP } \\
\text { Sayısı }\end{array}$ & Lezzet algısı ile ilişkili besinler & $\begin{array}{c}\text { Beslenme davranışı } \\
\text { ile ilişki }\end{array}$ \\
\hline TAS2R1 & 39 & - & 2 & - & - \\
\hline TAS2R3 & 1 & - & 1 & Espresso kahve & - \\
\hline TAS2R4 & 33 & Steviosid, Reb A-C, Kinin & 3 & Espresso kahve, Steviosid & Pirinç şarabı tüketimi \\
\hline TAS2R5 & 6 & $\begin{array}{c}\text { Denatonyum, EGCG, Sükraloz, } \\
\text { Prosiyanidin C2 }\end{array}$ & 2 & Espresso kahve & Pirinç şarabı tüketimi \\
\hline TAS2R7 & 12 & Kafein, Sukraloz & 2 & - & - \\
\hline TAS2R9 & 3 & Besin dışı ligandlar & 1 & Asesulfam K & - \\
\hline TAS2R10 & 45 & Kafein, Kumarin & 1 & - & - \\
\hline TAS2R13 & 2 & Denatonyum benzoat & 1 & Etanol & Alkol tüketimi \\
\hline TAS2R14 & 151 & Kinin, Kafein, Kumarin & 1 & Steviosid & - \\
\hline TAS2R16 & 13 & $\begin{array}{c}\text { Sodyum benzoat, Arbutin, } \\
\text { Sinigrin, Gentiobioz }\end{array}$ & 2 & - & Alkol tüketimi \\
\hline TAS2R19 & 0 & - & 1 & Kinin & - \\
\hline TAS2R20 & 3 & Besin dışı ligandlar & 7 & - & - \\
\hline TAS2R30 & 10 & Denatonium benzoat, D-Kafur & 2 & - & - \\
\hline TAS2R31 & 10 & Asesülfam K, Sakarin & 6 & Asesulfam K, Kinin & - \\
\hline TAS2R38 & 23 & $\begin{array}{l}\text { Sodyum siklamat, Sinigrin, Alil } \\
\text { İzotiyosiyanat, Limonin }\end{array}$ & 3 & Etanol & $\begin{array}{c}\text { Alkol, Sebze, Kahve } \\
\text { tüketimi }\end{array}$ \\
\hline TAS2R40 & 13 & Kinin, Cohumulone & 1 & - & - \\
\hline TAS2R41 & 2 & Sükraloz & 1 & - & - \\
\hline TAS2R42 & 0 & - & 7 & - & - \\
\hline TAS2R43 & 19 & Kinin & 2 & Aloin, Sakarin & Kahve tüketimi \\
\hline TAS2R45 & 0 & - & 2 & - & - \\
\hline TAS2R46 & 68 & Kafein, Kinin, Taurin & 1 & Kafein, Kinin & - \\
\hline
\end{tabular}


Ekşi tat, sinir sinyalinin doğrudan yayılmasına neden olan iyon kanallarının aktivasyonu ile hissedilir (13). Ekşi tatlar asitli besinler tarafından oluşmaktadır. İkizler üzerinde yapılan bir çalışmada ekşi tadın hoş algılanması \%14, his yoğunluğu \%31 ve besinlerin kullanım sıklığı \%34-50 oranında genetik varyasyon ile ilişkilendirilmiştir. Bu çalışma ekşi tadın genetik altyapısının lezzet algısını güçlü oranda etkilediğini göstermektedir (51). Üç potasyum kanalının (PKD2L1, PKD1L3 ve Kir2.1) ekşi tat iletisinde etkili olduğu bulunmuştur. Bu kanallar ekşi tatlara tepkilerin oluşmasını sağlamaktadır $(52,53)$.

Umami tadı genel olarak et tadı olarak algılansa da proteini yüksek gıdalarda özellikle tuzlu tada benzer olarak hissedilmektedir. En belirgin tat unsuru monosodyum glutamat (MSG) tuzudur. Normal sofra tuzu 1/400 oranında su çözeltisinde hissedilirken MSG 1/3000 oranında bile hissedilebilmektedir. Aynı zamanda bitki ve mantarlarda bulunan guanilat ve hayvansal kaynaklı inosinatta umami tadını oluşturmaktadır (54). TAS1R1 / TAS1R3 genleri umami tadın algılanmasından sorumlu olsa da SNP'ler lezzet algısı ve besin tüketimini değiştirebilmektedir. TAS1R3 rs307355 ve rs35744813'ün CC alelleri bulunan kişiler daha fazla protein, TAS1R1 rs34160967'nin GG genotipine sahip kişiler daha fazla yağ ve kalori tüketimi ile ilişkilendirilmiştir (55).

Beş temel tat unsuru dışında yakın zamanda yağların farkIı lezzet algısına neden olabileceği ve bunun altıncı bir tat (oleogustus tat) olarak değerlendirilmesi gerektiği belirtilmiştir. Bu tat algısının yağ asitlerinin uzunluklarına göre değişebileceği bildirilmiştir. Kısa zincirli yağ asitlerinde ekşiye benzer uzun zincirlilerde ise umamiyi andırır bir tat olduğu ama bu tadın farklı değerlendirilmesi gerektiği vurgulanmıştır (56). Karbonhidratlarla ilgili farklı tat unsurları da belirlenmiştir. Özellikle karbonhidratlarla sıklıkla ilişkilendirilen tatı tadın dışında nişastanın farklı bir lezzet algısı oluşturabileceği ve bunun tatlı tattan ayrı değerlendirilmesi gerektiği bildirilmiştir (57). Aynı zamanda bazı metal tuzlarının metalik tat olarak bilinen lezzet algısına neden olduğu bilinmektedir. TAS2R7'nin çinko, kalsiyum, magnezyum, bakır, manganez ve alüminyum dahil olmak üzere çok çeşitli iki ve üç değerlikli tuzlara yanıt verdiği bildirilmiştir. TAS2R7'nin çeşitli mineral tuzlarına karşı duyarlılığı, hem oral hem de diğer dokulardaki metal katyonları için kalsiyum algılayıcı reseptöre benzer geniş bir algılayıcı olarak işlev görebileceğini düşündürmektedir (58).

Kemestez, dokunma ve ağrı gibi algılara dayanan duyguları tanımlamaktadır. Besinlerin oral yolla alınması ile ağızda oluşan yanma, soğuma veya tahriş hislerinin genelini kapsamaktadır. Bu hisler sadece dil epitelinde değil vücudun farklı birçok bölgesinde de hissedilmektedir. Kemestezin mekanizması lezzet algısının oluşum mekanizmasından farklıdır. Bu nedenle bir tat olarak değil bir his veya duygu olarak değerlendirilmesi gerekmektedir (59). Oral kemes- tez, gıdalarda yaygın olarak bulunan tahriş edici bileşikler tarafından ortaya çıkarılır ve trigeminal sinir tarafından oral mukozadan taşınır. Bu maddeleri içeren besinler sık olarak tüketilmesine rağmen bu alanda çok fazla çalışma yapılmamıştır. Mentol, alkol, nane, biber gibi maddelerde bu etki gözlenmektedir $(59,60)$.

Lezzet algısı bireylerin besin tercihleri ve tüketimini etkileyen önemli bir unsurdur. Anne karnında başlayan ve küçük yaşlarda şekillenen lezzet algısı, yaşamın ilerleyen dönemlerinde beslenme davranışlarını, besin tercihlerini ve tüketimini etkilemektedir. İnsanlar hoşlarına giden lezzetleri barındıran besinleri daha sık tüketirken beğenmedikleri veya rahatsız oldukları besinleri tüketmekten kaçınmaktadır. Aynı zamanda gebelik veya hastalık dönemleri gibi bazı durumlarda lezzet algılarında değişiklikle birlikte beslenme durumu etkilenmektedir. Lezzet algısının oluşmasında çevresel faktörlerin yanında genetik farklılıklar ve genlerde meydana gelen polimorfizmler de etkilidir. Bu farklılıklar besin tercihlerinde etkili olduğu gibi hastalıklara temel oluşturabilir veya hastalıklardan koruyabilir. Bu nedenle sürdürülebilir sağlığın desteklenmesi için bu alanda çalışmalar son yıllarda artmış, bilinen beş tat duyusu dışında yağ, nişasta ve metalik tatlar gibi farklı konular da çalışılmıştır. Lezzet algısının altında yatan genetik ve çevresel mekanizmaların daha detaylı anlaşılması için kaliteli çalışmaların artması gerekirken, bu konu besin tercihlerinin anlaşılması ve çağımızın sorunu beslenme kökenli hastalıklarla mücadele konusunda büyük önem taşımaktadır.

\section{Teşekkür}

Derlemenin planlanmasındaki değerli yorumları için İstanbul Üniversitesi Çocuk Sağlığı ve Hastalıkları Anabilim Dalı Beslenme Doktora Programı hekimlerine ve diyetisyenlerine teşekkür ediyoruz.

Yazar Katkı Beyanı

Derlemenin planlanması, tasarımı, yazılması: Mücahit Muslu, derlemenin planlanması ve son gözden geçirmesi: Gülden Fatma Gökçay.

\section{Çıkar Çatışması}

Yazarlar arasında çıkar çatışması yoktur.

Finansal Destek

Bu çalışma için hiçbir kurum veya firmadan finansal destek alınmamıştır.

\section{Etik Kurul Onayı}

Derleme için etik kurul oluru gerekmemiştir.

\section{Hakemlik Süreci}

Kör hakemlik süreci yayınlanmaya uygun bulunmuş ve kabul edilmiştir. 


\section{KAYNAKLAR}

1. World Health Organization. Noncommunicable diseases country profiles 2018 [internet Yayını]. 2018 [atıf 25.07.2020].Erişim: https://www.who.int/publications/i/item/9789241514620.

2. Kourouniotis S, Keast RSJ, Riddell LJ, Lacy K, Thorpe MG, Cicerale S. The importance of taste on dietary choice, behaviour and intake in a group of young adults. Appet 2016;103:1-7.

3. Karakuş SŞ. Tat algılamayı etkileyen faktörler. Journal of Tourism and Gastronomy Studies 2013;26:34.

4. Diószegi J, Llanaj E, Ádány R. Genetic background of taste perception, taste preferences, and its nutritional implications: A systematic review. Front Genet 2019;10:1272.

5. Beauchamp GK. Basic taste: A perceptual concept. J Agric Food Chem 2019;67(50):13860-13869.

6. Kakutani Y, Narumi T, Kobayakawa T, Kawai T, Kusakabe Y, Kunieda S, Wada Y. Taste of breath: The temporal order of taste and smell synchronized with breathing as a determinant for taste and olfactory integration. Sci Rep 2017;7(1):1-9.

7. Shaikh FH, Soni A. Physiology, Taste. StatPearls [internet Yayını]. 2020 April 29 [atıf 25.07.2020].Erişim: https://www. ncbi.nlm.nih.gov/books/NBK557768/

8. Batu A. Moleküler gastronomi bakış açısıyla gıdaların tat ve aroma algıları. Aydın Gastronomy 2017;1(1):25-36.

9. Witt M. Anatomy and development of the human taste system. Handb Clin Neurol 2019;164:147-171.

10. Janssen S, Depoortere I. Nutrient sensing in the gut: New roads to therapeutics? Trends Endocrin Met 2013;24(2):92-100.

11. Kandemir S, Muluk NB. Koku fizyolojisi ve koku testleri: Derleme. Turk J Clin Lab 2016;7(2):48-53.

12. Yaparel C, Elmacı Y. Tat-koku interaksiyonları. Akademik Gıda $2016 ; 14(2)$

13. Vincis R, Fontanini A. Central taste anatomy and physiology Handb Clin Neurol 2019;164:187-204.

14. Paglia L. Taste development and prenatal prevention. Eur $J$ Paediatr Dent 2019;20(4):257-257.

15. Schwartz C, Chabanet C, Laval C, Issanchou S, Nicklaus S. Breast-feeding duration: Influence on taste acceptance over the first year of life. Br J Nutr 2013;109:1154-1161.

16. Andreas NJ, Kampmann B, Le-Doare KM. Human breast milk: A review on its composition and bioactivity. Early Hum Dev 2015;91:629-635.

17. Mennella JA. Beauchamp GK. Flavor experiences during formula feeding are related to preferences during childhood. Early Hum Dev 2002;68:71-82.

18. Lauzon-Guillain B, Jones L, Oliveira A, Moschonis G, Betoko A, Lopes C, Moreira P, Manios Y, Papadopoulos NG, Emmett $P$, Charles MA. The influence of early feeding practices on fruit and vegetable intake among preschool children in 4 European birth cohorts. Am J Clin Nutr 2013;98(3):804-812.

19. Fewtrell M, Bronsky J, Campoy C, Domellöf M, Embleton N, Mis NF, Hojsak I, Hulst JM, Indrio F, Lapillonne A, Molgaard C. Complementary feeding: A position paper by the European Society for Paediatric Gastroenterology, Hepatology, and Nutrition (ESPGHAN) Committee on Nutrition. J Pediatr Gastr Nutr 2017;64(1):119-132.

20. Kabaran S. Yaşamın erken dönemlerinde yaşanan lezzet deneyimleri besin tercihlerini nasıl etkiliyor? Güncel Pediatri $2017 ; 15(1)$
21. Steensels S, Depoortere I. Chemoreceptors in the gut. Annu Rev Physiol 2018;80:117-141.

22. Shahbandi A, Choo E, Dando R. Receptor regulation in taste: Can diet influence how we perceive foods? J Multidiscip Sci J 2018;1:106-115.

23. Song X, Giacalone D, Johansen SMB, Frøst MB, Bredie WL. Changes in orosensory perception related to aging and strategies for counteracting its influence on food preferences among older adults. Trends Food Sci Technol 2016;53:49-59.

24. Barragán R, Coltell $O$, Portolés $O$, Asensio EM, Sorlí JV, Ortega-Azorín C, González JI, Sáiz C, Fernández-Carrión R, Ordovas JM, Corella D. Bitter, sweet, salty, sour and umami taste perception decreases with age: Sex-specific analysis, modulation by genetic variants and tastepreference associations in 18 to 80 year-old subjects. Nutr 2018;10(10):1539.

25. Imoscopi A, Inelmen EM, Sergi G, Miotto F, Manzato E. Taste loss in the elderly: Epidemiology, causes and consequences. Aging Clin Exp Res 2012;24(6):570-579.

26. Puputti S, Aisala H, Hoppu U, Sandell M. Factors explaining individual differences in taste sensitivity and taste modality recognition among Finnish adults. J Sens Stud 2019;34(4):e12506.

27. Guido D, Perna S, Carrai M, Barale R, Grassi M, Rondanelli M. Multidimensional evaluation of endogenous and health factors affecting food preferences, taste and smell perception. J Nutr Health Aging 2016;20(10):971-981.

28. Koubaa Y, Eleuch A. Gender effects on odor-induced taste enhancement and subsequent food consumption. J Consum Mark 2020

29. Ammann J, Hartmann C, Siegrist M. A bitter taste in the mouth: The role of 6-n-propylthiouracil taster status and sex in food disgust sensitivity. Physiol Behav 2019;204:219-223.

30. Joseph PV, Reed DR, Mennella JA. Individual differences among children in sucrose detection thresholds: Relationship with age, gender, and bitter taste genotype. Nurs Res 2016;65(1):3

31. Tarlarini C, Greco LC, Lizio A, Gerardi F, Sansone VA, Lunetta C. Taste changes in amyotrophic lateral sclerosis and effects on quality of life. Neurol Sci 2019;40(2):399-404.

32. Schalk P, Kohl M, Herrmann HJ, Schwappacher R, Rimmele ME, Buettner A, Siebler J, Neurath MF, Zopf Y. Influence of cancer and acute inflammatory disease on taste perception: A clinical pilot study. Suppor Care Cancer 2018;26(3):843-851.

33. Roura E, Foster S, Winklebach A, Navarro M, Thomas W, Campbell K, Stowasser M. Taste and hypertension in humans: Targeting cardiovascular disease. Curr Pharm Des 2016;22(15):2290-2305.

34. Kubota M, Nagai A, Higashiyama Y. Taste perception in pediatric clinical settings: A review. Open J Nutr Food Sci 2019;1(1):1006.

35. Rohde K, Schamarek I, Blüher M. Consequences of obesity on the sense of taste: Taste buds as treatment targets? Diabetes Metab J 2020;44:e19.

36. Cattaneo C, Riso P, Laureati M, Gargari G, Pagliarini E. Exploring associations between interindividual differences in taste perception, oral microbiota composition, and reported food intake. Nutr 2019;11(5):1167. 
37. Fasunla AJ, Nwankwo U, Onakoya PA, Oladokun A, Nwaorgu OG. Gustatory function of pregnant and nonpregnant women in a Tertiary Health Institution. Ear Nose Throat J 2019;98(3):143148.

38. Weenen H, Olsen A, Nanou E, Moreau E, Nambiar S, Vereijken C. Changes in taste threshold, perceived intensity, liking, and preference in pregnant women: A literature review. Chemosens Percep 2019;12(1):1-17.

39. Kale YS, Vibhute N, Belgaumi U, Kadashetti V, Bommanavar $\mathrm{S}$, Kamate W. Effect of using tobacco on taste perception. Fam Med Prim Care Rev 2019;8(8):2699.

40. Panduro A, Rivera-Iñiguez I, Ramos-Lopez O, Roman S. Genes and alcoholism: Taste, addiction, and metabolism. Neuroscience of Alcohol 2019:483-491.

41. Williams JA, Bartoshuk LM, Fillingim RB, Dotson CD. Exploring ethnic differences in taste perception. Chem Sense 2016;41(5):449-456.

42. Roper SD, Chaudhari N. Taste buds: Cells, signals and synapses. Nat Rev Neurosci 2017;18(8):485-497.

43. Behrens M, Gunn HC, Ramos P, Meyerhof W, Wooding SP. Genetic, functional, and phenotypic diversity in TAS2R38mediated bitter taste perception. Chem Senses 2013;38(6):475484

44. Li D, Zhang J. Diet shapes the evolution of the vertebrate bitter taste receptor gene repertoire. Mol Biol Evol 2014;31(2):303309.

45. Blakeslee AF. Genetics of sensory thresholds: Taste for phenyl thio carbamide. Proc Natl Acad Sci U S A 1932;18(1):120.

46. Nolden AA, Feeney EL. Genetic differences in taste receptors: Implications for the food industry. Annu Rev Food Sci Technol 2020;11:183-204.

47. Cui M, Jiang P, Maillet E, Max M, Margolskee RF, Osman R The heterodimeric sweet taste receptor has multiple potential ligand binding sites. Curr Pharm Des 2006;12(35):4591-4600.

48. Zhao GQ, Zang Y, Hoon MA, Chandrashekar J, Erlenbach I, Ryba NJ, Zuker CS. The receptors for mammalian sweet and umami taste. Cell 2003;115(3):255-266.
49. Heck GL, Mierson S, DeSimone JA. Salt taste transduction occurs through an amiloride-sensitive sodium transport pathway. Sci 1984;223:403-405.

50. Dias AG, Rousseau D, Duizer L, Cockburn M, Chiu W, Nielsen D, El-Sohemy A. Genetic variation in putative salt taste receptors and salt taste perception in humans. Chem Senses 2013;38(2):137-145.

51. Törnwall O, Silventoinen K, Keskitalo-Vuokko K, Perola M, Kaprio J, Tuorila H. Genetic contribution to sour taste preference. Appet 2012;58:687-694

52. Challis RC, Ma M.Sour taste finds closure in a potassium channel. PNAS 2016;113:246-47.

53. Ye W, Chang RB, Bushman JD, Tu YH, Mulhall EM, Wilson CE, Cooper AJ, Chick WS, Hill-Eubanks DC, Nelson MT Kinnamon SC, Liman ER. The K+ channel KIR2.1 functions in tandem with proton influx to mediate sour taste transduction. PNAS 2016;113:229-238.

54. Mouritsen OG, Styrbak K, editors. Umami: unlocking the secrets of the fifth taste. New York: Columbia University Press; 2014.

55. Han $\mathrm{P}$, Keast R, Roura E. TAS1R1 and TAS1R3 polymorphisms relate to energy and protein-rich food choices from a buffet meal respectively. Nutr 2018;10(12):1906.

56. Running CA, Craig BA, Mattes RD. Oleogustus: The unique taste of fat. Chem Senses 2015;40(7):507-516.

57. Lim J, Pullicin AJ. Oral carbohydrate sensing: Beyond sweet taste. Physiol Behav 2019;202:14-25

58. Wang Y, Zajac AL, Lei W, Christensen CM, Margolskee RF, Bouysset C, Golebiowski J, Zhao H, Fiorucci S, Jiang P. Metal ions activate the human taste receptor TAS2R7. Chem Sense 2019;44(5):339-347.

59. McDonald ST, Bolliet DA, Hayes JE, editors. Chemesthesis: chemical touch in food and eating. West Sussex: John Wiley \& Sons; 2016.

60. Simons CT, Carstens E. Oral chemesthesis and taste. The senses: A comprehensive reference. 2008;4:345-369. 